\title{
A KAFKAESQUE AGE ASCESIS AND BIOPOLITICS
}

\author{
Mirko Alagna \\ Università degli Studi di Milano-Bicocca
}

DOI: 1017450/160212

“The animal twists the whip out of its master's grip and whips itself to become its own master." Many have recognized a distinctive feature of our age in this false syllogism, in the blunder of mistaking emancipation for the willingness to whip oneself in sovereign autonomy. Many concepts already pertaining to the philosophical realm have been invoked in an attempt to understand this ostensible absurdum, this scandal of critical thought; some have described the mechanisms and the paradigm shift operated by 'the New Spirit of Capitalism', ${ }^{2}$ others have brought the term of 'Voluntary Servitude'3 back from early modernity. These are different sides of the same coin: the 'New Way of the World', the apical point of neoliberal governmentality.

The amount of bibliographical references mentioned till now already shows that this brief incipit is indeed a compendium of some of the most interesting analyses of our contemporaneity; but even though the object of investigation may be the same, this does not imply that its various diagnoses should be, too. Better still, the card that this work intends to play is that of a forced, maximized differentiation. I will try to emphasize the distance separating the diagnoses provided by Boltanski and Chiapello, on the one hand, and by Dardot and Laval on the other -even at the risk of stepping beyond the limits authorized by strict textual exegesis. The goal of this move is the building of two 'pure types' of contemporary governmental mechanisms. Two ideal types that, as

\footnotetext{
1. F. Kafka, The Zürau Aphorisms, Hervill Secker - Penguin Random House, London, 2006, p. 29.

2. See L. Boltanski, E. Chiapello, The New Spirit of Capitalism, Verso Books, London, 2005.

3. See Collettivo La Boétie, "Investire se stessi", in E. Donaggio (ed.), C’è ben altro. Criticare il capitalismo oggi, Mimesis, Milano, 2014.

4. See P. Dardot, C. Laval, The New Way of the World. On Neoliberal Society, Verso Books, London, 2013.
} 
suggested by Max Weber, do not claim an immediate accuracy in describing the real, but rather serve a heuristic function, supplying the diagnosing scholar with a categorical system and a measurement unit. An attempt at enlarging the field of vision will then be added to this modeling, resorting to Sloterdijk's ascetic anthropology; its role will be that of a filter, of a sieve able to distinguish, as in a precipitate, the contemporary situation's specificities.

\section{They Seduced Us. The Kafkaesque Age According to Boltanski and Chiapello}

There is a brilliant strategic insight at the heart of the change of pace represented by neoliberalism: the exploitation of and the emphasis on differences and distances within the enemy camp, the playing out of a kind of criticism against the other. Facing a joint attack by 'social criticism' (focused on inequality and on the demand for a redistribution of wealth) and by 'artistic criticism' (focused on the loss of creativity and autonomy necessary in order to adapt to the system) capitalism chose, since the 1970s, to deal first and foremost with the latter. Better still, it managed to use, absorb and take on the accusations coming from artistic criticism as an incentive, a movebo, for its own radical renewal -a renewal that allowed it to marginalize and neutralize the front of social criticism.

This is, in a nutshell, the historical-strategical reconstruction proposed by Boltans$\mathrm{ki}$ and Chiapello. In this context, the premise or implicit precondition of such a reconstruction is crucial: that is to say, according to Boltanski and Chiapello capitalism must convince, and cannot simply coerce. According to Weber, each form of capitalism must therefore have a spirit capable of actively involving the individuals that are necessary to the production; indeed, it must prove somewhat attractive, it must seduce. Thus, 'reticular' capitalism has managed to absorb and redirect the very demands for self-realization, cooperation, and autonomy that used to be the watchwords of its critics. So begins the age of mass self-realization rhetoric, formally incentivized by the capitalist system. No more blue-collar crowds locked up in the assembly line, repeating the same monotonous gestures all day long, no more white-collar employees walled in the same office for life; the symbol of the new age of capitalism is the multitasking creative professional, innovative and hungry for new experiences, who would never barter the thrill and risk of unexpected events for the dull routine of bureaucrats, employees, or laborers. 
Alienation versus self-realization: this is the distinction that, according to neomanagement textbooks, separates the second and the third spirit of capitalism, and that ends the economic history of the short century ten years in advance. The capitalism of the new millennium does not need alienated crowds anymore, but rather searches for and stimulates versatile subjects, capable of getting enthusiastic about a project, who want to fulfill themselves in their job and can thusly convey all of their energy into their work. The psycho-linguistic trick is as easy as it is brilliant in presenting an equation with winners only: fulfill yourself in your job, so that you will do a good job. One does not need to sacrifice aspects of one's personality anymore: personality, soft skills and relational tendencies become elements that one should give value to -in the double acceptation of the term: they ought to be complied with and nurtured in order to create value. In the capitalism's hagiographic self-presentation, a world of unlimited potential is described: each and every one is free -and encouraged- to search for self-fulfillment in their job, to develop relationships, and to hold on to their passions, keeping an open possibility for change and for reinventing themselves.

The power of this rhetorical front overshadows the downsides of a life that is given value to: if one is the sole maker of one's own biography and sole responsible for one's own destiny, one is also the only culprit of a potential failure. Victim blaming: there is a "transformation of external causes into individual guilt, of systemic problems into personal failure." ${ }^{5}$ The rhetoric of self-realization, capitalist style, becomes an impressive alibi in order to grant moral and political immunity to the world's status quo: the failure of a life project is not the system's fault, but rather a symptom of the subject's inadequacy -it points to an insufficiency in the process of self-realization for which the subject is the one and sole responsible. Insult and injury.

\section{They Forced Us. The Kafkaesque Age According to Dardot and Laval}

As soon as this malaise becomes apparent enough, it is necessary to strike those who oppose change -and this has to be done in the most overt and sensational way, so as to inspire fear or to offer positive example to the rest of the organization.

5. U. Beck, Risikogesellschaft - Auf dem Weg in eine andere Moderne, Suhrkamp, Frankfurt am Main, 1986, p. 150 (my translation). 
This has to be done quickly, firmly [...] and in a few months the organization will understand, because people don't like to suffer ${ }^{6}$.

People do not like to suffer: this is the mantra, the fundamental assumption guiding and directing the new neoliberal worldview. It is a tautology with a dark side: it implies, in fact, that it is necessary to "inspire fear", to propose a horizon of suffering and exclusion from the social game to those who resist change, those who feel extraneous to the dogma of efficiency and molecular competitiveness.

Two major differences, duly emphasized, set Dardot's and Laval's diagnosis apart from that of Boltanski and Chiapello. First, on a historic-genealogical level, Dardot and Laval reject the idea of an intentional design behind the neoliberal shift. There has been no great conspiracy, nor any specific doctrinaire corpus cynically and willingly implemented by politics in order to benefit their powerful businessman friends, ${ }^{7}$ but rather the merging, almost at random, of different and heterogeneous regulatory interventions, cultural battles, economical and business choices. Neoliberalism as a coherent set, as the fundamental rationality of the contemporary world, only exists ex post.

Secondly, Dardot and Laval are more suspicious of the cultural self-presentation of the age, recognizing the ideological fabric of managerial discourse; thus, the focus is not just on the clinical and psychological price paid by the subject-self-entrepreneur, but also on how this subject is forced to live in a state of constant tension and forced to be adaptive. There is no way out of the iron cage -just the serial production of new, customized cages. Constraint and obligation: the semantic field of discipline occupies the foreground of the stage of the new worldview. Of course, it does not carry the brutal, explicit features of sovereign imposition anymore, but it still crystallizes in a "global disciplinary system" "with high ratios of endemic violence. If the final result is the complete internalization of this discipline, intermediate steps consist in a pervasive environmental setup that is contemporarily developed on several fronts: "Every subject has been led to think of themselves, and to behave in every dimension of their existence, as the holder of capital to be valorized." University courses are subject to a fee and individual retirement funds, monetarist state policies, the very concrete threat of unemployment and the evaporation of any counterpart thanks to systemic injunctions

\footnotetext{
6. F. Starace, CEO of Enel, in a conference at the Luiss University in Rome (reported in Internazionale, no. 1155, 2016, p. 3 -my translation).

7. P. Dardot, C. Laval, The New Way of the World. On Neoliberal Society, Verso, London - New York, 2013

8. P. Dardot, C. Laval, The New Way of The World, p. 173.

9. Ibid., p. 176.
} 
imposed by 'customer' and 'competition'; these are relatively independent and heterogeneous moves that, however, merge in the forced constitution of a subject-enterprise compelled to capitalize his or her own life and constantly bound to choose, and to take on full responsibility for these very choices. Henceforth, the mechanism reproduces itself automatically:

The novelty consists in triggering a 'chain reaction' by producing 'enterprising subjects' who in turn will reproduce, expand and reinforce competitive relations between themselves. In accordance with the logic of the self-fulfilling prophecy, this requires them to adapt subjectively to even harsher conditions which they have themselves created ${ }^{10}$.

\section{Every Age is Kafkaesque. Sloterdijk's Ascetic Anthropology}

In this very short paragraph, we will take (more than) one step back, in order to observe the whole picture and reduce the ratio of the perceived eccentricity of the present. According to Sloterdijk's reconstruction, what we call 'human being' is, from head to toe, a product ${ }^{11}$, the result of a sequence of exercises and repetitions, of regulations and disciplines. It has always been that way. This process of constant training does not happen, of course, in a vacuum, but rather within 'Human Zoos', cultural constructs (not foreign to practices of power) themselves composed by a coherent set of given anthropotechniques, that is to say, of the habits and dominant exercises: humans are, therefore, ascetic animals in the sense that they are "creatures that live in the enclosure of disciplines, involuntary and voluntary ones alike." ${ }^{12}$ The subject is thus built upon a fabric of habits, training exercises and disciplines, so there is no 'adaptation' as an idle, painless self-abandonment to the world being as such: adaptation, too, takes effort as it involves the implementation and the somewhat voluntary acceptance of specific training schedules. Kafka's pulp tone aside, there always is two whips, one for the master and one for ourselves; in this context, the mechanism of subjectivization emerges as a mixture of individual needs and systemic injunctions, historical perceptions of what is 'true' and 'natural' and sincere, authentic ambitions for self-improvement.

10. Ibid., p. 291.

11. See P. Sloterdijk, Nicht gerettet. Versuche nach Heidegger, Suhrkamp, Frankfurt am Main, 2001.

12. P. Sloterdijk, You Must Change Your Life, Polity Press, Cambridge, 2013, p. 109. 
If man, then, is ascetic by definition, the fundamental question becomes the choice among the anthropotechniques available in the market of the various training gyms. The swerve, which is always possible, happens when the subject decides that he or she has lived till now in a bad gym, where bad habits set, and chooses to change exercises and trainers; breaking habits in favor of a different kind of training marks the distinction "from the side of the merely formed to that of the forming" ${ }^{13}$, the subject's taking charge of him -or herself, the free choice of development exercises to be implemented, in which lies the ability to consciously shape one's own life. Such a breaking of one's habits always implies a crossing of the desert -be it literal or pocket-sized, prêt-à-porter; not just and not quite as an empty-space allowing for practical experimenta mundi, but rather as an other-space, an outdoor-space, in which a distance toward the rest of the world can be gained. The desert allows problematizing the obvious and the commonplace, and in so doing it allows one to look detachedly at one's habits; recognizing them as such -and therefore as techniques among the many possible ones- is the first precondition in order to choose freely one's training exercises.

\section{The Contemporary Gym. Training Exercises of the Kafkaesque Age}

Have all ages, then, been Kafkaesque? Only up to a point. A clear change of pace is marked, in fact, by neoliberal governmentality: we could say, with an already used slogan, that the sign of the times lies in the act of giving value to life as a whole. The first innovative feature is thus a qualitative one: the celebration of the undisputed centrality of economics, which are not only taken as a paradigm, but as an authentic foundation to which every other facet of life is to be connected. There is no leeway for economically irrational ascetic practices leading to the development of other spheres of life, for it is only within economics that the chances of self-realization are played out and it is there where the outcome of an existential project is determined. The second feature is a quantitative one: life as a whole is involved in the process of economic self-valorization and of market development. There are no indifferences, no facets of life that can be taken away from a strategic approach; from physical appearance to personality, from friendships to hobbies, everything has to be object of economically oriented ascetic practices, every-

13. Ibid., p. 195. 
thing has to be modified and finalized for the development of the self qua enterprise. This is the plan of truth that we are dealing with. In other words, there are no deserts anymore -or rather, it is more and more difficult to find places for decompression, distancing spaces from which one can look detachedly at one's own everyday life.

But if man is his own exercises, what kind of training and what kind of trainers prevail in the contemporary scene? In order to get this, we must move from business school textbooks for aspiring managers to the tangle of bestsellers with titles such as Leader of Yourself, Reinventing Your Life, or the chart-topping book The Ultimate Secret to Getting Absolutely Everything You Want ${ }^{14}$. These are actual 'ascetic textbooks', indicating practices for those who cannot become business managers -lacking the necessary technical, economical, juridical skills- but want to become managers in, and of, their own daily life. The reader is obsessively requested to practice his or her soft skills: always and everywhere one has to be extroverted, or better yet enthusiastic, always ready to establish new connections; one has to be fun, somebody that is nice and pleasant to spend some time with; friendships, hobbies, sports, volunteering, everything can and must become a chance for new, economically advantageous relationships, because time cannot be wasted and the distinction between unselfish friendly relationships and useful professional ones has disappeared. In a word, one needs to work on oneself on a deep level, not quite in order to acquire new skills, but rather in order to modify one's personality and become a cheerful person -because nobody wants to deal with depressed folks, and because this is the only way to achieve success.

This is the obsessively repeated keyword: success. Economic success is the goal and the mantra of these ascetic textbooks for the masses. This allows to recalibrate the idea according to which contemporary capitalism makes itself attractive by means of proposing professional self-realization; the exercise for today is not quite the search for a job that allows space for one's talents and inclinations, but rather it is the training for the employment of each and every 'talent' and 'inclination' in order to achieve economic success. The difference might appear minimal, but it is in fact radical. In the first case, self-realization is meant as the possibility to work a job that can define us, i.e. one that is stimulating, exciting, and appropriate to our skills and hopes -so that one can say, for instance, "I am a football player" and not just "I play football". In the second case, self-realization is meant as self-valorization and as social recognition extorted through economic success.

14. The latter, a bestseller of the last decade, has been written by M. Hernacki, New York, Berkeley, 2001. 
This is the only way to solve the ostensible contradiction of an age that flaunts demands for professional self-realization while offering a dramatically inadequate social mobility. What is striking is not, of course, the inaccessibility of power positions to those who come from below, but rather the monotonous genetic heredity of jobs for members of the privileged classes. Even in 2007 (and therefore before the crisis, that presumably increased the phenomenon) $43.9 \%$ of architects in Italy had a son or a daughter who was an architect, $42 \%$ of jurists had a jurist one, $40.8 \%$ of pharmacists had a pharmacist one $^{15}$, whereas a fair share of members of the youth branch of the General Confederation of Italian Industry had demonstrated their proactivity by means of inheriting the family's company. It is, at least, statistically unlikely that so many sons of architects or pharmacists may dream of becoming, respectively, architects and pharmacists. In this capitalist version of the Ancien Régime, precisely those who might risk with relative ease the search for self-realization in innovative activities (having, presumably, access to a family financial capital) actually follow slavishly in their fathers' or mothers' footsteps.

An ostensible contradiction indeed, and one that is immediately solved if we retranslate 'self-realization' into 'self-valorization': being (economically) successful means having brought a life project to a positive ending, having been able to give value to oneself, having been right. This is indeed what merit is in the age of a 'life that is given value to', and here are the exercises that one ought to practice: developing a talent for seeing anywhere a potential competitive advantage, and being willing to exploit it for good -independently, if needs be, of its moral record. 